\title{
Correlation Of Resilience And Spatial Ability In Distance Material
}

\author{
Destia Wahyu Hidayati ${ }^{1}$ Arie Wahyuni ${ }^{2}$ \\ ${ }^{1}$ Universitas Ivet, Semarang \\ Email: destia281289@gmail.com \\ ${ }^{2}$ Universitas Ivet, Semarang \\ ariewahyuni20@gmail.com
}

(Received: 02-05-2020; Reviewed: 13-05-2020; Revised: 24-06-2020; Accepted: 27-06-2020; Published: 1-07-2020)

\begin{abstract}
Spatial material was material that was very useful in everyday life. Students often had difficulty in imagining spatial objects. Students would had no difficulty in imagining spatial objects if they had good spatial ability. Resilience was needed to learn spatial ability. The purpose of this study was to determine whether there was a relationship between resilience and spatial ability and how many the coefficient correlation was, and to find out dominant indicators of resilience so that there was a relationship between resilience and spatial ability in students in the upper, middle, and lower groups. This research was a qualitative-quantitative mixed research. The research instrument was used a test of spatial ability in distance and resilience scale material. The data analysis technique was used the correlation test and data triangulation method. The conclusions of this study were (1) there was a relationship between resilience and spatial ability of 56\%, (2) indicators of resilience 'willing to socialize, easy to provide assistance, discuss with peers, and adapt to the environment' were dominant in the upper, middle, and lower groups, resilience indicator 'use failure experiences to build self-motivation' was dominant in the upper group, resilience indicators 'show curiosity, reflect, examine, utilize a variety of dominant sources in the upper group, indicators of resilience perseverance, confidence, work hard, not easy to give up facing problems, failures and uncertainties' were dominant in the lower classes.
\end{abstract}

Keyword: correlation, spatial ability, resilience

\section{Introduction}

Spatial material is material that must be studied in mathematics. Spatial material is also very useful in daily life because objects in daily life are manifestations in spatial material(Alfaruqi \& Lutfianto, 2016). Spatial ability will affect spatial material understanding(Jelatu, Mandur, Jundu, \& Kurniawan, 2018). Learning spatial material will look easy for students if the object can be found in real time. This is the opposite if the object can not be found in real, then students will have difficulty in imagining. Students will have no difficulty in imagining spatial objects if they have good spatial ability. Spatial ability is the ability to visualize two-dimensional or three-dimensional objects(Hutagalung \& Harahap, 2018). Indicators of spatial ability are spatial relationships, projective relationships, frame of reference, mental rotation, spatial representation, and distance conservation(Asis, Arsyad, \& Alimuddin, 2015). Spatial ability is very important not only in learning in schools, but also to obtain work that is recognized globally(Yilmaz, 2009). One predictor of mathematical achievement is spatial ability(Jelatu et al., 2018).

Not all students can do activities that require spatial roles and abilities easily. A strong effort is needed to carry out these activities. Students who have difficulty developing spatial abilities can simply give up and do not want to continue efforts to achieve learning goals. This effort does not only need the support of external factors that are facilities and infrastructure in completing it, but also requires an internal factor that is resilience. Resilience is persistence in doing mathematical challenges. Indicators of mathematical resilience are (1) perseverance, confidence and confidence, not easily giving up working hard, not easily giving up doing problems, failures and uncertainties, (2) willing to socialize, 
easy to provide assistance, discuss with peers, and adapt to the environment, (3) facilitating new ideas / ways and finding creative solutions to challenges, (4) using the experience of failure to build selfmotivation, (5) showing curiosity, reflecting, researching, utilizing various sources, and (6) having language skills, control yourself and be aware of their feelings(Maharani \& Bernard, 2018).

The existence of thoughts that are in line between resilience and spatial ability, then this study has the formulation of the problem, $\mathrm{t}$ (1) Is there a relationship between resilience and spatial ability? (2) What indicators of resilience are dominant so that there is a relationship between resilience and spatial ability of students in the upper, middle, and lower groups? The purpose of this study is to determine whether there is a relationship between resilience and spatial ability and how many the coefficient correlation is, and to find out dominant indicators of resilience so that there is a relationship between resilience and spatial ability in students in the upper, middle, and lower groups. The benefit of this research is to provide information to educators that learning should give contributes to increasing resilience that will affect spatial ability.

Research on resilience has been done before. There was a positive relationship between gender and resilience to the ability to think creatively(Dilla, Hidayat, \& Rohaeti, 2018). There was a correlation between mathematical resilience and problem solving ability(Maharani \& Bernard, 2018). Research on spatial ability also has been done before. Students who have a visual learning style had better spatial ability than students who have an audio learning style(Alfaruqi \& Lutfianto, 2016). Mathematical learning outcomes were influenced by spatial ability of 46,55\%(Harmony \& Theis, 2012). Indicators of spatial ability based on gender, namely the frame of reference and mental rotation (men tended to use spatial abilities while women tended to use logical reasoning), distance conservation (men and women lacked the use of spatial abilities and tended to logic), spatial representation and relationships projective (male and female were using spatial ability and logic)(Asis et al., 2015). The difference between this research and the previous one is this research looked for the relationship between resilience and spatial ability and described in depth about the dominant indicators of resilience so that there was a relationship between resilience and spatial ability in students in the upper, middle, and lower groups.

\section{Research Method}

The subjects of this research were 8 students of the Ivet University Mathematics Education Study Program which would be divided into 3 parts 1 ) the top $27 \%$ of the data were grouped into the upper group, 2) the bottom $27 \%$ of the data were grouped into the lower group, and 3) the rest are the middle group. Each group will take 2 students to be interviewed. This research held on march 2020.

This research was quantitative-qualitative mixed research. Quantitative research methods used correlation tests while qualitative research methods use data triangulation that are digesting and searching for the essence of test data, scale, and interviews.. Data collection procedures used in this study are tests, scales, and interviews.

The test instrument was used a spatial ability test. The scale was used ithe scale of resilience where the choice of answers has a score of 1,2,3, and 4, and interviews are conducted based on interview guidelines that have been made previously. Data analysis techniques used to answer the first problem formulation are the normality test and the correlation test. The data analysis technique used to answer the second problem statement is to use the Think Aloud method.

\section{Result And Discussion}

From the result of research that the relationship between resilience and spatial ability was $56 \%$. This is supported by previous research that there was a correlation between resilience and mathematical ability (Asih, Isnarto, Sukestiyarno, \& Wardono, 2019; Hutauruk \& Priatna, 2017). There were several indicators of spatial ability that had been seen in the upper, middle, and lower groups. Spatial indicators had been seen in the upper group were spatial relationships, projective relationships, distance conservation, and mental rotation. This was supported by previous research that students who had high ability to recognize changes in objects after rotation(Febriana, 2015). Spatial ability affected students' 
mathematical thinking abilities(Altiner \& Doğan, 2018). Obstacles occured in indicators 'terms of reference and spatial representation', that was relation between spatial knowledge was not optimal. The ability to read symbols in a building could also describe spatial abilities(Harmony \& Theis, 2012). It was seen that the process of finding solutions to spatial problems in the distance material was still wrong. There are also respondents in the upper group that still did not provide perpendicular notation to the picture.

The indicator shown in the middle group was same as the upper group except the distance limit. The difference was in the middle group occured in distance conservation and spatial representation. Students in the middle group had difficulty in spatial representation(Febriana, 2015). Responses in the middle group did not provide perpendicular and equal notations in the image. The students in the middle group still confused by the concept of crossing lines. Respond in this middle group could not estimate the distance between points on a cube, so the image looks like not a cube but a block.

The indicator in the lower group was almost same as the upper group except mental rotation. So the difference in the lower group occured in distance conservation, spatial representation, and mental rotation too. Mental rotation was one indicator of spatial ability that was felt difficult by students(Rahmatulwahidah \& Zubainur, 2017). Respondents had difficulty to give the name of the vertex when the frontal plane changed from the initial image. Respondents also had difficulty in digesting the problem and putting it in the picture. Students at low levels had difficulty seeing objects in different perspectives(Febriana, 2015). Students in the lower group experienced incomplete thought processes(Sari, Syahputra, \& Surya, 2018).

Indicators were said to be dominant if each respondent in the upper, middle, and lower classes scores 3 or 4 for each item contained in the indicator. There were three dominant indicators of resilience in the upper classes. The first indicator was the desire to socialize, easy to provide assistance, discuss with peers, and adapt to the environment. The ability to adapt to the environment showed that respondents did not easily panic if they suddenly had difficulty in solving spatial problems. This was consistent with previous research that students who were in the upper group did not feel anxiety which has an effect on despair when solving problems(Kusumawati \& Nayazik, 2017). The second indicator was using the experience of failure to build self-motivation. The ability to motivate herself /himself after failure showed that the respondent was able to re-energize the existing enthusiasm for learning and improving the situation. The third indicator was showing curiosity, reflecting, researching, utilizing various sources. The high curiosity in solving spatial problems makes respondents would try without desperation to solve these problems to completion. Respondents would do a variety of ways including utilizing various sources of knowledge. Students who had high abilities tended to be more resilient when doing a challenge(Afriyanti, Sri, \& Asih, 2018; Dilla et al., 2018). Curiosity through interactive learning could increase spatial ability(Septia, Charitas, Prahmana, \& Wahyu, 2018).

The dominant indicator of resilience in the middle group was almost same as the upper group except the indicator uses the experience of failure to build self-motivation. Students who had middle abilities tended to want to socialize and discuss with peers(Afriyanti et al., 2018). Respondents in the middle group had inability to motivate themselves. Respondents felt sad and could not interpret failure when doing on spatial problems.

There were two dominant indicators of resilience in the lower group. The first indicator was perseverance, confidence, working hard, not easy to let go of problems, failures and overcome. Difficulties in solving spatial difficulties could be solved using analytic strategies(Evidiasari, Subanji, \& Irawati, 2019). Respond at the lower group who had unyielding attitude to do the problem and also had a strong sense of confidence. This over-confidence wass not balanced by the accuracy and ability to link spatial knowledge with spatial representation. Students in low groups tried to solve problems but the strategies did not appropriate(Maharani \& Bernard, 2018). The second indicator was desire to socialize, easy to provide assistance, discuss with peers, and support the environment. Respondents in the lower group would find help to consider the process of spatial knowledge through discussions with peers because they could remind each other. Students in low groups would rely on help from 
peers(Afriyanti et al., 2018). The process of mentoring from peers could increase resilience(Ariyanto, Herman, Sumarmo, \& Suryadi, 2017).

\section{Conclusion And Recommendation}

\section{Conclusion}

The conclusions of this study are (1) there is a relationship between resilience and spatial ability, (2) Resilience indicators are dominant in the upper group that is willing to socialize, easy to provide assistance, discuss with peers, and adapt to the environment, use the experience of failure to build self-motivation, and showing curiosity, reflecting, researching, utilizing various sources, (3) indicators of resilience that are dominant in the middle group that is willing to socialize, easy to help, discuss with their peers, and adapt to the environment and show curiosity, reflect, examine, utilizing various sources, (4) dominant indicators of resilience in the lower group, namely perseverance, confidence / confidence, working hard, not easily giving up on problems, failures and uncertainties and wanting to socialize, easy to provide assistance, discuss with peers, and adapt with the environment

\section{Recommendation}

This research can be continued with research that discusses the efforts by educators in increasing resilience for the upper, middle, and lower groups so as to improve spatial ability.

\section{References}

Afriyanti, I., Sri, T., \& Asih, N. (2018). Mathematical Literacy Skills Reviewed From Mathematical Resilience in The Learning of Discovery Learning Assisted by Schoology. Unnes Journal of Mathematics Education Research, 7(23), 71-78.

Alfaruqi, A. ., \& Lutfianto, M. (2016). Perbandingan kemampuan spasial siswa sma pada materi geometri ditinjau dari gaya belajar siswa. Sminar Nasional Pendidikan Matematika AHmad Dahlan 2016, 13-17. Yogyakarta.

Altiner, E. C., \& Doğan, M. C. (2018). Investigating The Spatial Reasoning Skills of Students In The Context Of Mathematical Thinking Profiles. European Journal of Education Studies, 4(11), 2638. https://doi.org/10.5281/zenodo.1318323

Ariyanto, L., Herman, T., Sumarmo, U., \& Suryadi, D. (2017). Developing Mathematical Resilience of Prospective Math Teachers. International Conference on Mathematics and Science Education (ICMScE), 1-5.

Asih, K. S., Isnarto, Sukestiyarno, \& Wardono. (2019). Resiliensi Matematis pada Pembelajaran Discovery Learning dalam Upaya Meningkatkan Komunikasi Matematika. PRISMA, Prosiding Seminar Nasional Matematika, 2, 862-868.

Asis, M., Arsyad, N., \& Alimuddin. (2015). Profil Kemampuan Spasial dalam Menyelesaikan Masalah Geometri Siswa yang Memiliki Kecerdasan Logis Matematis Tinggi Ditinjau dari Perbedaan gender (Studi Kasus di Kelas XI SMAN 17 Makassar). Jurnal Daya Matematis, 3(1), 78-87.

Dilla, S. C., Hidayat, W., \& Rohaeti, E. E. (2018). Faktor gender dan resiliensi dalam pencapaian kemampuan berpikir kreatif matematis siswa sma. Journal of Medives, 2(1), 129-136.

Evidiasari, S., Subanji, \& Irawati, S. (2019). Students' Spatial Reasoning in Solving Geometrical Transformation Problems. Indonesian Journal on Learning and Advanced Education, 1(2), 3851. https://doi.org/10.23917/ijolae.v1i2.8703

Febriana, E. (2015). PROFIL KEMAMPUAN SPASIAL SISWA MENENGAH PERTAMA ( SMP ) DALAM MENYELESAIKAN MASALAH GEOMETRI DIMENSI. Jurnal Elemen, 1(1), 13-23.

Harmony, J., \& Theis, R. (2012). Pengaruh Kemampuan Spasial Terhadap Hasil Belajar Matematika Siswa Kelas VII SMP Negeri 9 Kota Jambi. Edumatica, 02(01), 11-19.

Hutagalung, A., \& Harahap, M. S. (2018). PENINGKATAN KEMAMPUAN SPASIAL SISWA MELALUI PENGGUNAAN MODEL AUDITORY INTELLECTUALLY REPETITION ( AIR ) DI SMP NEGERI 1 PINANGSORI. JURNAL MathEdu (Mathematic Education Journal), 1(1), $15-23$.

Hutauruk, A. J. B., \& Priatna, N. (2017). Mathematical Resilience of Mathematics Education 
Daya Matematis: Jurnal Inovasi Pendidikan Matematika, Vol. 8 No. 2 July 2020

Students. International Conference on Mathematics and Science Education (ICMScE), 1-6. Jelatu, S., Mandur, K., Jundu, R., \& Kurniawan, Y. (2018). Relasi Antara Visualisasi Spasial dan Orientasi Spasial Terhadap Pemahaman Konsep Geometri Ruang. JOURNAL OF SONGKE MATH, 1(1), 47-59.

Kusumawati, R., \& Nayazik, A. (2017). Kecemasan Matematika Siswa SMP Berdasarkan Gender. Journal of Medives, 1(2), 92-99.

Maharani, S., \& Bernard, M. (2018). Analisis hubungan resiliensi matematik terhadap kemampuan pemecahan masalah siswa pada materi lingkaran. Jurnal Pembelajaran Matematika Inovatif, $1(5), 819-826$.

Rahmatulwahidah, N., \& Zubainur, C. M. (2017). The Analysis of Students' Spatial Ability at Senior High School in Banda Aceh. Proceedings of The 7th Annual International Conference (AIC) Syiah Kuala University, 745-752.

Sari, D. P., Syahputra, E., \& Surya, E. (2018). An Analysis of Spatial Ability and Self-efficacy of Students in Cooperative Learning by Using Jigsaw at Smas Muhammadiyah 8 Kisaran. American Journal of Educational Research, 6(8), 1238-1244. https://doi.org/10.12691/education-6-8-25

Septia, T., Charitas, R., Prahmana, I., \& Wahyu, R. (2018). Improving Students Spatial Reasoning With Course Lab. Journal on Mathematics Education, 9(2), 327-336.

Yilmaz, B. (2009). On the development and measurement of spatial ability. International Electronic Journal of Elementary Education, 1(2), 83-96. 